\title{
Analisis Investigasi Forensik WhatsApp Messenger Smartphone Terhadap WhatsApp Berbasis Web
}

\author{
Nuril Anwar ${ }^{1}$, Imam Riadi ${ }^{2}$ \\ ${ }^{1}$ Program Studi Teknik Informatika, Universitas Ahmad Dahlan \\ ${ }^{2}$ Program Studi Sistem Informasi, Universitas Ahmad Dahlan \\ Jalan Prof. Dr. Soepomo, S.H. Janturan Yogyakarta 55164 \\ e-mail: nuril.anwar@tif.uad.ac.id ${ }^{1}$, imam.riadi@is.uad.ac.id²
}

\begin{abstract}
Telecommunication in Indonesia has increased rapidly since the internet-based instant messaging service. WhatsApp is the most popular instant messaging application than any other instant messaging service, according to statistics website website users as of January 2017 as many as 1.2 billion people are actively using this application. Along with the WhatsApp update the various features embedded in this application include Web-Based Whatsapp for Computers, this feature allows users to share certain files and can be synchronized to the smartphone or computer users. In addition to the positive benefits that the application WhatsApp also provides vulnerabilities for the privacy of users, one of which is tapping a conversation that involves both devices; Smartphones and computers. The handling of crimes involving digital devices needs to be emphasized so as to assist the judicial process for its effects. The Digital Forensics investigation contributes to the abuse of WhatsApp Instant messaging service features such as the investigation of the handling of the WhatsApp conversation through a series of standard steps in accordance with digital forensics procedures. Exploration of the evidence (digital evidence) WhatsApp conversation will be a reference to the crime of telecommunication tapping which will then be conducted investigation forensics report involving evidence of smartphone and victim's computer.
\end{abstract}

Keyword : forensics; investigation; whatsapp messenger web.

\begin{abstract}
Abstrak
Perkembangan telekomunikasi meningkat sangat pesat semenjak layanan pesan instan berbasis internet merambat cepat ke Indonesia. WhatsApp adalah aplikasi pesan instan paling populer dibanding layanan pesan instan lain, menurut situs website statista pengguna per Januari 2017 sebanyak 1,2 miliar orang secara aktif menggunakan aplikasi ini. Seiring pembaruan WhatsApp berbagai fitur disematkan dalam aplikasi ini diantaranya Whatsapp Berbasis Web untuk Komputer, fitur ini mempermudah pengguna dalam berbagi file tertentu serta dapat tersinkronisasi terhadap smartphone maupun komputer penggunanya. Disamping sisi positif yang didapati aplikasi, WhatsApp juga memberikan celah keamanan akan privasi penggunanya salah satunya yaitu penyadapan percakapan yang melibatkan kedua devices ; smartphone dan komputer. Penanganan tindak kejahatan yang melibatkan piranti digital perlu ditekankan sehingga dapat membantu proses peradilan akan efek yang ditimbulkannya. Investigasi Forensika Digital turut berperan serta terhadap penindakan penyalahgunaan fitur layanan pesan instan WhatsApp diantaranya langkah investigasi penanganan kasus penyadapan percakapan WhatsApp melalui serangkaian tahapan baku sesuai prosedur forensika digital. Eksplorasi barang bukti (digital evidence) percakapan WhatsApp akan menjadi acuan akan tindak kejahatan penyadapan telekomunikasi yang selanjutnya akan dilakukan report investigation forensics yang melibatkan barang bukti smartphone dan komputer korban.
\end{abstract}

Kata kunci : forensik; investigasi; whatsapp messenger web.

Analisis Investigasi Forensik WhatsApp Messenger Smartphone Terhadap WhatsApp Berbasis 


\section{Pendahuluan}

Pertumbuhan eksponensial media sosial dan aplikasi pesan instan telah memfasilitasi pengembangan banyak kejahatan cyber dan aktivitas jahat yang serius [12]. Penjahat dunia maya terus mengubah strategi mereka untuk menargetkan media sosial yang berkembang pesat dan pengguna pesan yang ketat. Penyalahgunaan media sosial dan pesan instan dalam layanan mobile memungkinkan penjahat dunia maya memanfaatkan layanan ini untuk tujuan jahat [14] seperti menyebarkan kode berbahaya, dan mendapatkan dan menyebarkan informasi rahasia. Banyak media sosial dan penyedia pesan instan telah memperluas layanan mereka ke platform empiris, [3] yang memperburuk situasi karena pengguna berada dalam bahaya kehilangan lebih banyak lagi informasi pribadi [8].

Menurut data statistik website statista menunjukkan jumlah pengguna WhatsApp aktif bulanan di seluruh dunia per-Januari 2017. Pada bulan tersebut, aplikasi perpesanan mobile mengumumkan lebih dari 1,2 miliar pengguna aktif bulanan, naik dari lebih dari 1 miliar pada bulan Februari 2016. Layanan ini salah satu aplikasi seluler terpopuler di seluruh dunia. WhatsApp adalah layanan pesan cepat lintas platform untuk smartphone yang mengandalkan internet untuk pengiriman pesan. Berdasarkan model berlangganan berbiaya rendah, WhatsApp adalah alternatif yang murah untuk mengirim pesan teks melalui SMS, terutama untuk pesan internasional atau grup. Aplikasi perpesanan mobile memungkinkan pengguna berbagi pesan teks, gambar dan video. Di Amerika Serikat, pengguna WhatsApp berjumlah 18,8 juta pengguna pada tahun 2016 dan diperkirakan akan tumbuh menjadi 25,6 juta pengguna pada tahun 2021. [17]

WhatsApp adalah aplikasi pesan untuk smartphone yang mampu berjalan lintas platform diantaranya ; Apple iOS, BlackBerry, Android, Symbian Nokia Series 40 dan Windows Phone. WhatsApp Messenger menggunakan paket data internet sama halnya seperti layananan email, browsing web, dan layanan instant messengers lainnya. Aplikasi WhatsApp Messenger menggunakan koneksi data mobile serta WiFi untuk melangsungkan komunikasi data, dengan menggunakan WhatsApp, seseorang dapat melakukan obrolan online, berbagi file, bertukar foto dan fitur lainnya yang menarik penggunanya. [5]

WhatsApp secara resmi mengumumkan peluncuran fitur resmi bernama WhatsApp Web pada tanggal 22 Januari 2015. Fitur ini mencoba memfasilitasi penggunaan aplikasi ini untuk pengguna berbasis komputer. Sepertihalnya WhatsApp berbasis smartphone, fitur ini membutuhkan koneksi internet sebagai jalur penyampaikan informasi. WhatsApp bekerja melalui portal online yang disediakan oleh domain. WhatsApp Web pada prinsipnya berfungsi untuk membuka akun WhatsApp melalui perangkat komputer. Fitur ini pada periode awal lebih mudah digunakan melalui aplikasi browser. Sinkronisasi dibutuhkan untuk membuka akun WhatsApp melalui web. Pengembang menyediakan barcode yang perlu dipindai melalui aplikasi WhatsApp mobile. Pemindaian akan secara langsung membuka aplikasi Whatsapp sesuai dengan akun yang berfungsi pada telepon genggam yang digunakan untuk pemindaian. Percakapan yang terdapat pada aplikasi WhatsApp di telepon seluler akan turut disajikan pada versi web. Sinkronisasi akan dilakukan secara otomatis apabila terjadi perubahan pada salah satu aplikasi yang aktif. [16]

Mubarak Al-Hadadi and Ali AIShidhani (2013). Forensik Smartphone adalah bagian dari forensik digital, dan mengacu pada penyelidikan dan perolehan artefak pada smartphone. Ancaman baru terhadap ponsel membuat ilmu forensik menjadi tantangan yang menantang dalam beberapa tahun terakhir. Jumlah pengguna ponsel meningkat di seluruh dunia dan menimbulkan masalah dan tantangan yang luar biasa. Literatur yang relevan dengan forensik smartphone, fokus penelitian ini pada arsitektur sistem operasi smartphone dan teknik antiforensik. Ini juga membahas bukti digital dari aplikasi smartphone. Dalam penelitian ini, melalui pertimbangan jenis kejahatan yang melibatkan smartphone, sebuah studi kasus nyata dari Negara Kesultanan Oman dipresentasikan. Studi kasus ini melakukan eksperimen praktis terhadap sumber yang teridentifikasi untuk bukti yang nantinya dapat digunakan dalam sistem peradilan.[9]

Imam Riadi, Rusydi Umar and Arizona Firdonsyah (2017). Teknologi smartphone semakin populer pertahunnya. Salah satu teknologi dengan jumlah pengguna yang terbanyak adalah smartphone berbasis androids sebagai sistem operasinya. Android cukup kompetitif di dalam pasar smartphone. Jumlah pengguna smartphone android juga memberi efek untuk pengembangan dan penggunaan aplikasi mobile, termasuk aplikasi instant messenger diantaranya aplikasi yang banyak digunakan adalah Blackberry Messenger (selanjutnya disingkat sebagai BBM). Meningkatnya jumlah pengguna BBM tentu membawa efek positif dan negatif, salah satunya efek negatifnya adalah beberapa orang yang menggunakan BBM melakukan meningkatkan tindak kejahatan digital seperti pornografi dan kecurangan, jika 
smartphone menjadi bukti dalam kasus pidana dan BBM dipasang di smartphone itu, di sini aplikasi bukti digital dapat diidentifikasi dan dapat juga diharapkan menjadi pilihan untuk membantu penegakan hukum dalam mengungkap kejahatan digital. Adapun cara penelitian ini dilakukan dengan berbagai macam metode yang dapat digunakan dalam proses analisis forensik dan Identifikasi bukti digital, metode yang digunakan dalam penelitian ini adalah metode forensik mobile yang didasarkan pada ketersediaan pedoman yang disiapkan oleh National Institute of Standards dan Teknologi (NIST). Hasil penelitian disajikan pada bentuk rekaman percakapan, BBM Personal Identification Nomor (PIN BBM), nama pengirim dan penerima, dan waktu percakapan (timestamp) diharapkan dapat memberikan lkhtisar langkah-langkah yang dapat diterapkan di bidang analisis forensik android.[6]

Thakur, Neha S (2013). Forensik Android telah berkembang dari waktu ke waktu dengan menawarkan peluang dan tantangan menarik yang signifikan. Di satu sisi, menjadi platform open source Android memberi pengembang kebebasan untuk berkontribusi pada pertumbuhan pasar Android yang pesat, sementara di sisi lain pengguna Android mungkin tidak menyadari implikasi keamanan dan privasi pemasangan aplikasi ini di ponsel mereka. Pengguna mungkin menganggap bahwa perangkat yang terkunci sandi melindungi informasi pribadi mereka, namun aplikasi mungkin menyimpan informasi pribadi pada perangkat, dengan cara yang mungkin tidak diantisipasi pengguna. Dalam penelitian ini akan berkonsentrasi pada satu aplikasi yang disebut 'WhatsApp', aplikasi jejaring sosial yang populer. Penelitia akan membentuk garis besar tentang bagaimana penyidik forensik dapat mengekstrak informasi yang berguna dari WhatsApp dan dari aplikasi serupa yang terpasang di platform Android. Area fokus penelitian adalah ekstraksi dan analisis data pengguna aplikasi dari penyimpanan eksternal non-volatile dan memori volatile (RAM) perangkat Android.[15]

Guntur Maulana Zamroni, Rusydi U, Imam R (2016). Instant Messaging (IM) merupakan salah satu aplikasi seluler yang sangat popular. Salah satu jenis aplikasi IM adalah WhatsApp (WA). Pengguna WA jumlahnya mencapai 1 Milyar setiap bulannya. WA didukung oleh fitur enkripsi untuk menjamin keamanan data para penggunanya. Kepopuleran dan fitur yang diberikan WA dapat disalahgunakan masyarakat untuk tujuan kriminal, seperti perdagangan narkoba, kegiatan teroris, perencanaan pembunuhan, dan kegiatan kriminal lainnya melalui fiturfitur yang tersedia. Pihak berwenang dapat menggunakan data-data dalam WA sebagai barang bukti. Metode forensik diperlukan untuk memastikan keberhasilan proses pengambilan data-data tersebut. Penelitian ini akan menjelaskan langkah-langkah untuk memperoleh data aplikasi WA, dari data yang telah dienkripsi menjadi data yang dapat dibaca dan dianalisis untuk kemudian dapat digunakan sebagai barang bukti. [4]

Daniel Walnycky (2015). Secara forensik memperoleh dan menganalisis data yang tersimpan perangkat dan lalu lintas jaringan dari 20 aplikasi pesan instan yang populer untuk Android. investigator dapat mengkonstruksikan beberapa atau seluruh isi pesan dari 16 dari 20 aplikasi yang diuji yang mencerminkan keburukan pada tindakan keamanan dan privasi yang digunakan oleh aplikasi ini, namun dapat dianggap positif untuk tujuan pengumpulan bukti digital oleh praktisi forensik digital. Penelitian ini menunjukkan fitur aplikasi pesan instan mana yang meninggalkan jejak pembuktian yang memungkinkan data tersangka direkonstruksi sebagian, dan apakah forensik jaringan atau forensik perangkat memungkinkan dilakukannya rekonstruksi aktivitas tersebut. Peneliti menunjukkan bahwa dalam banyak kasus dapat merekonstruksi data seperti : kata sandi, screenshot yang diambil oleh aplikasi, gambar, video, audio yang dikirim, pesan yang dikirim, sketsa, gambar profil dan lain-lain.[1]

Berdasarkan pernyataan peneliti terdahulu diatas dapat dikembangkan Analisis Investigasi Forensik WhatsApp Messengersmartphone terhadap WhatsApp berbasis Web dengan studi kasus penyadapan percakapan WhatsApp, dengan mempertimbangkan beberapa aspek seperti pernyataan peneliti terdahulu penelitian lanjutan dihadapkan pada berbagai jenis perangkat smartphone selama penanganan kasus investigasi forensik [7]. Perangkat smartphone saat ini menjadi sumber penting digital evidence yang relevan dengan pengguna media sosial dan aktivitas instan Messenger[13]. Namun, perbedaan antara perangkat smartphone menjadi tantangan penyidik atau investigator forensik untuk mengembangkan metode dan teknik yang disesuaikan untuk penyelidikan berbagai kasus cybercrime[11].

\section{Metode Penelitian}

Data WhatsApp disimpan dalam memori Internal smartphone setelah pekage installer WhatsApp ter-install, secara otomatis sinkronisasi dengan kontak telepon menunjukkan pengguna yang sudah menggunakan WhatsApp. Saat ponsel dengan installer WhatsApp dihidupkan, Proses "com.whatsapp" menerima sinyal untuk memulai layanan 'ExternalMediaManage' dan 'MessageService' yang Berjalan di latar belakang telepon sampai 
telepon dinyalakan. Dengan dukungan versi baru WhatsApp Web yang berjalan dikomputer, setelah dilakukan scan $Q R$ Code WhatsApp yang terjadi sinkronisasi dengan aplikasi WhatsApp on Smartphone baik itu kontak telepon, percakapan dan data yang melekat di smartphone penggunanya dapat pula diakses melalui WhatsApp Web. Hal ini menunjukkan pengguna yang sudah menggunakan WhatsApp Web memiliki tingkat vulnerability, dimana pesan WhatsApp yang terdapat di smartphone dapat pula diakses di WhatsApp Web dengan kata lain kemungkinan dilakukan penyadapan bilamana komputer atau smartphone digunakan dalam satu waktu oleh orang lain tanpa sepengatahuan penggunanya maka memungkinkan pula pelaku penyadapan dapat mengkases percakapan obrolan secara detail termasuk gambar, video, kontak dan sebagainya.

Masalah utama setelah terjadi sinkronisasi data WhatsApp smartphone dan komputer adalah intervensi pihak yang terlibat penyalahgunaan layanan (penyadapan aplikasi dual WhatsApp), sehingga muncul gagasan atau desain dan rancangan usulan WhatsApp Investigation meliputi beberapa kompunen utama baik tahapan investigasi serta ditekankan pada poin dasar diantaranya meliputi :

- WhatsApp Evidence ; berupa fisik dari smartphone dan komputer korban beserta tindak kriminal dan penanganannya.

- Riset Goal Investigation Methode ; proses penanganan barang bukti dari memperoleh, akuisisi serta merepresentasikan skema kasus.

- Forensics Tools Investigator; merupakan software forensic dalam hal ekplorasi, eksaminasi dan reporting berkenaan terhadap barang bukti penyadapan WhatsApp.

- Digital Evidence Risk ; Resiko yang ditimbulkan pasca penyadapan berupa layanan WhatsApp ; Chat, File Sharing dan sinkronisasi, serta komputer browser (WhatsApp Web) memerlukan penanganan yang lebih terkait akuisisi data dari WhatsApp Web tersebut.

Tahapan proses penanganan investigasi penyadapan WhatsApp setelah dikondisikan terhadap skema kasus serta pengembangan tahapan investigasi mobile forensik dan network forensik maka dapat diperoleh tahapan seperti pada Tabel 1 [10].

Tabel 1. Proses Investigasi Penyadapan Percakapan WhatsApp

\begin{tabular}{|c|c|c|c|c|c|}
\hline Identification & Preservation & Collection & Examination & Analysis & Presentation \\
\hline $\begin{array}{l}\text { Identifikasi } \\
\text { kejahatan } \\
\text { WhatsApp }\end{array}$ & $\begin{array}{l}\text { Pengolahan } \\
\text { kasus } \\
\text { WhatsApp }\end{array}$ & $\begin{array}{l}\text { Pengaman } \\
\text { an barang } \\
\text { bukti } \\
\text { WhatsApp }\end{array}$ & $\begin{array}{l}\text { Pelacakan } \\
\text { barang bukti } \\
\text { WhatsApp }\end{array}$ & $\begin{array}{l}\text { Komparasi } \\
\text { data } \\
\text { investigasi }\end{array}$ & Dokumentasi \\
\hline $\begin{array}{l}\text { Profil } \\
\text { kejahatan } \\
\text { WhatsApp }\end{array}$ & $\begin{array}{l}\text { Chain of } \\
\text { custody/ } \\
\text { kronologis } \\
\text { WhatsApp } \\
\text { Attack }\end{array}$ & $\begin{array}{l}\text { Teknik } \\
\text { investigasi } \\
\text { WhatsApp }\end{array}$ & $\begin{array}{l}\text { Validasi } \\
\text { barang bukti } \\
\text { WhatsApp }\end{array}$ & $\begin{array}{l}\text { Pengolahan } \\
\text { temuan } \\
\text { barang } \\
\text { bukti }\end{array}$ & $\begin{array}{l}\text { Klarifikasi } \\
\text { invistigator }\end{array}$ \\
\hline \multirow[t]{3}{*}{$\begin{array}{l}\text { Audit dan } \\
\text { analisa kasus }\end{array}$} & $\begin{array}{l}\text { Manajemen } \\
\text { waktu } \\
\text { investigasi }\end{array}$ & & $\begin{array}{l}\text { Filtering } \\
\text { barang bukti }\end{array}$ & & $\begin{array}{l}\text { Pernyataan, } \\
\text { saran dan } \\
\text { tindakan }\end{array}$ \\
\hline & $\begin{array}{l}\text { Pengolahan } \\
\text { kasus } \\
\text { WhatsApp }\end{array}$ & & $\begin{array}{l}\text { Pencocokan } \\
\text { barang bukti }\end{array}$ & & $\begin{array}{l}\text { Interpretasi } \\
\text { data } \\
\text { WhatsApp }\end{array}$ \\
\hline & & & $\begin{array}{l}\text { Penemuan } \\
\text { data } \\
\text { tersembunyi }\end{array}$ & & \\
\hline
\end{tabular}


Berdasarkan Tabel 1. Proses Investigasi penyadapan percakapan WhatsApp diatas diperoleh penekanan pada poin yang diberi tanda warna berbeda, sebagai tahapan yang memerlukan penanganan yang lebih menurut porsi atau peran investigator digital forensik khususnya smartphone dengan aplikasi WhatsApp.

\subsection{Simulasi Penyadapan Percakapan WhatsApp}

Rancangan simulasi penyadapan percakapan WhatsApp dalam hal ini akan dijelaskan skema pengujian aplikasi WhatsApp sebagai dalam hal ini menyangkut keberadaan barang bukti digital pasca terjadi penyadapan, sehingga diketahui respon terhadap masing-masing aplikasi antara WhatsApp pada Smartphone terhadap WhatsApp Web tampak seperti Gambar 1 :

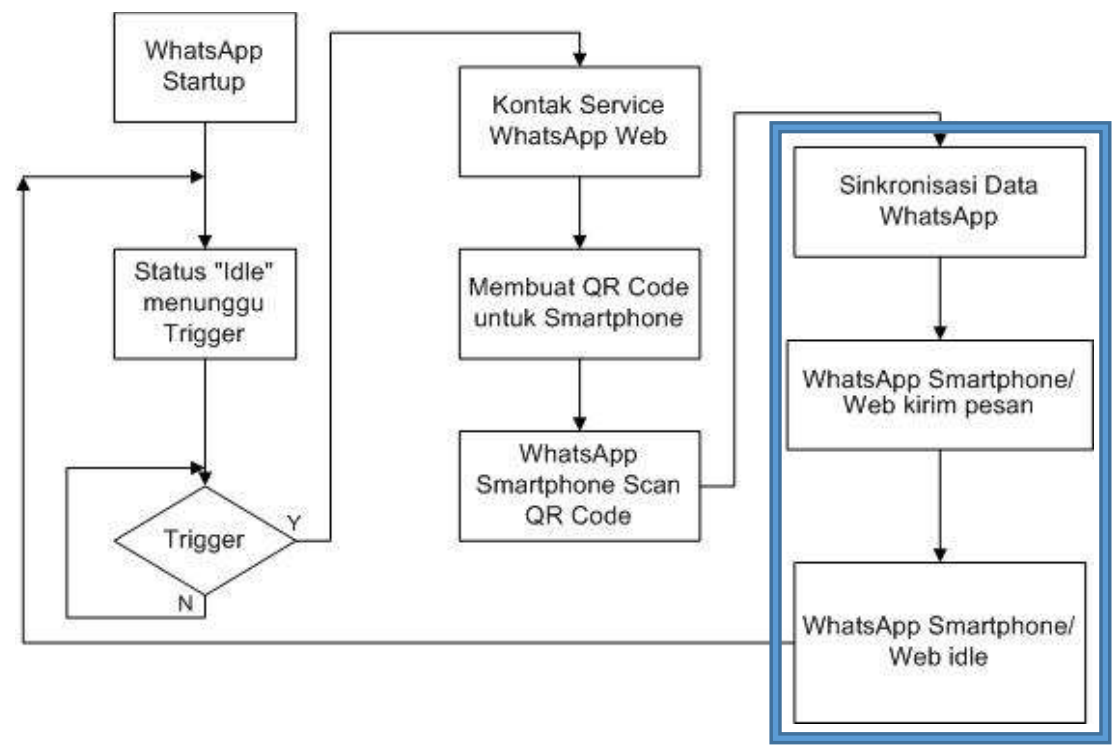

Gambar 1. Alur Kerja Serangan WhatsApp

Simulasi penyadapan percakapan WhatsApp dari Gambar diatas difokuskan pada sinkronisasi data baik data WhatsApp pada smartphone ataupun pada web browser, selanjutnya kedua aplikasi tersebut sampai dapat mengakses aplikasi secara bersamaan secara identik. Lebih lengkapnya dapat dilihat pada gambar yang diberi rectangle diatas.

\subsection{Flowchart Serangan WhatsApp}

Flowchart Penyadapan WhatsApp merupakan penyesuaian terhadap simulasi penyadapan percakapan WhatsApp pada bagian sebelumnya, selanjutnya dikondisikan terhadap prinsip kerja terjadinya serangan, hal ini dapat dikatakan seperti penyadapan serta bagaimana motif kejahatan ini dapat terjadi seperti halnya penyalahgunaan privasi percakapan. Modifikasi dari prinsip kerja pentest WhatsApp dari Gambar 1. berupa diagram alir dari seluruh proses Traffic Chanel Attack untuk selanjutnya dikomparasi dengan keadaan terjadinya penyadapan melalui pesan singkat WhatsApp sesaat setelah dilakukannya Attack yang sesuai dengan tema penelitian sehingga diperoleh diagram alur proses baru yang sesuai dengan penelitian terkait WhatsApp yang melibatkan penyalahgunaan wewenang layanan telekomunikasi yakni dalam hal ini membaca pesan tanpa sepengetahuan pemilik akun (penyadapan) serta pelaku juga dapat mengirim pesan WhatsApp, sehingga tercipta alur proses baru seperti tampak pada diagram proses pada Gambar 2 dibawah.

Dengan diterapkannya metode investigasi WhatsApp forensik yang melibatkan skema proses yaitu pentest WhatsApp attack dan flowchart penyadapan WhatsApp maka akan diperoleh hasil perbandingan investigasi terhadap dua devices mencakup WhatsApp on Smartphone dengan sistem operasi Android dan WhatsApp Web on komputer yang ber-platform Windows sehingga nantinya terdapat tabel normalisasi perbandingan akan ekplorasi temuan digital evidence yang menyatakan tindak kejahatan kaitannya dengan pesan layanan WhatsApp massanger. 


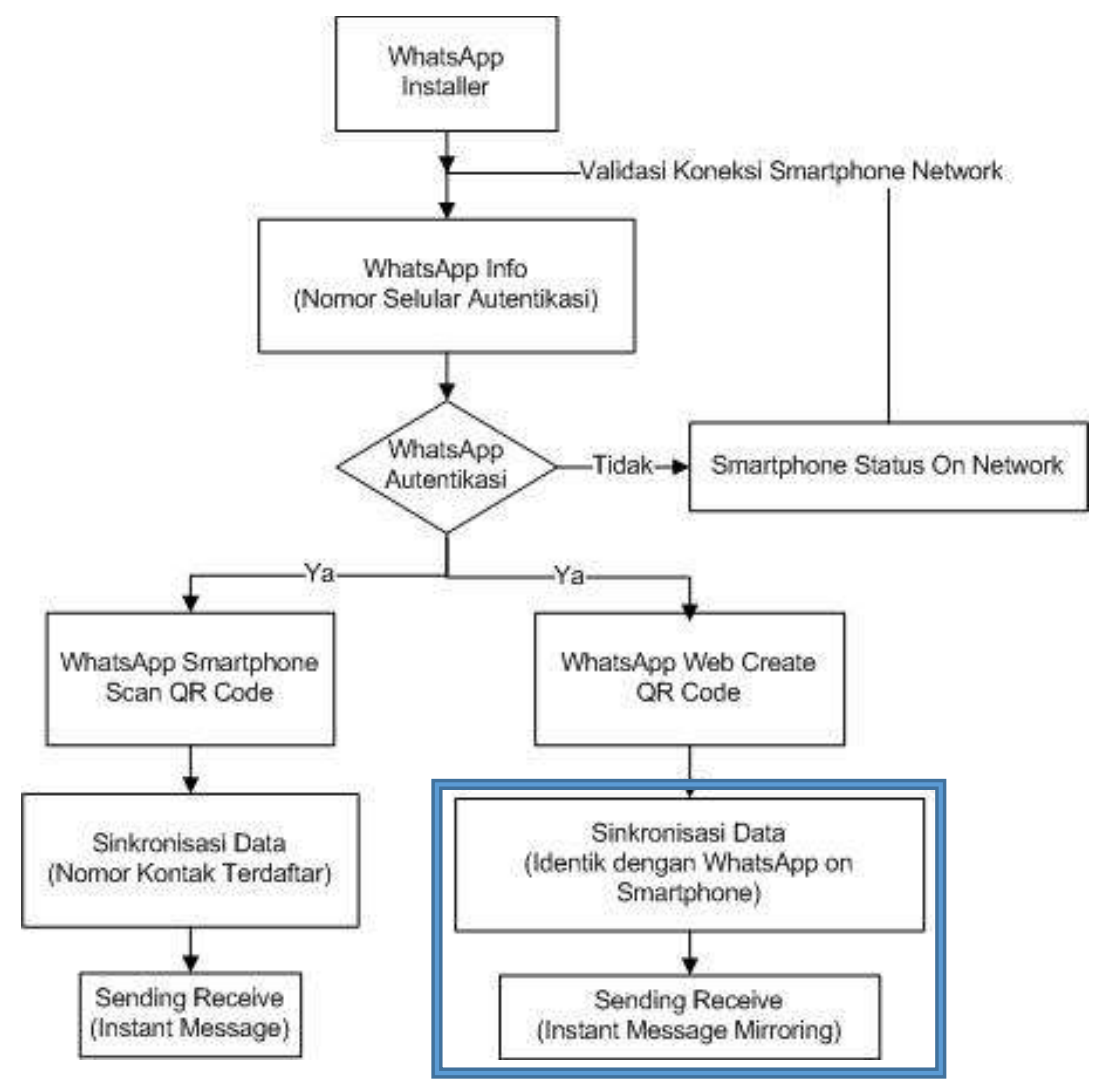

Gambar 2. Flowchart Penyadapan WhatsApp

Motif kejahatan dengan pemanfaatan sinkronisasi dual aplikasi baik yang terdapat pada smartphone atau pada aplikasi web browser dapat terjadi bilamana smartphone korban tentunya dalam keadaan status on network data akses, demikian pula aplikasi web browser juga diutuhkan akses internet. Bilamana smartphone korban tidak dalam keadaan terkoneksi dengan internet dengan kata lain pelaku tindak kejahatan yang akan memanfaatkan sinkronisasi data WhatsApp tidak akan memperoleh data yang terbarukan up to date pasca sinkronisasi data WhatsApp. Skema tersebut dapat diperjelas pada flowchart penyadapan percakapan WhatsApp, yang berkaitannya dengan tingkat kerentanan atau vulnerability sebuah aplikasi pesan instant.

\section{Analisis dan Hasil}

Digital Forensik dengan barang bukti WhatsApp pada Smartphone dan WhatsApp Web Brwoser akan menghasilkan komparasi dual digital evidence yang melibatkan lintas platform yaitu Android (mobile forensics) dan Windows (computer forensics), kedua sistem operasi tersebut menghasilkan karakteristik yang berbeda, baik dari tahap akuisisi barang bukti, penanganan, ekplorasi sampai pelaporan investigasi.

\section{1. $\quad$ Android (Mobile Forensics)}

Mobile Forensics dapat dilakukan pada berbagai smartphone, akan tetapi pada penelitian ini lebih difokuskan pada forensik smartphone ber-platform Android. Seiring meningkatnya jumlah smartphone yang kaya berbagai fitur membuat tantangan dalam membuat tools investigasi forensik atau standar khusus untuk masing-masing platform. Bukti digital dalam perangkat mobile memiliki sifat yang mudah rentan tertimpa dengan data baru atau bahkan terhapus. Perangkat mobile sendiri menggunakan memori internal (flash memory), meskipun tidak menutup kemungkinan ekternal memori juga dapat dilakukan prose investigasi digital karena melibatkan penyimpanan data satu sama lain. Keuntungan menggunakan flash memory adalah ketahanannya terhadap suhu dan tekanan yang tinggi sehingga lebih sulit untuk dihancurkan. Dilihat dari sudut pandang forensik hal ini menguntungkan invesigator karena flash memory dapat berisi informasi yang sudah dihapus bahkan setelah seseorang berusaha untuk menghancurkan barang bukti masih dapat dilakukan recovery data. 
Menurut E.Casey Tumbull, menjelaskan mengapa perangkat mobile merupakan sumber berharga sebagai bukti digital dan berisi informasi penting yang tidak tersedia pada perangkat lain. Selain itu sifat personaliti dari perangkat tersebut membuatnya mudah untuk membuktikan jejak yang mengaitkan perangkat ke individu [2]

\section{- Shared Preference}

Android menyediakan tiga cara untuk menyimpan data di device. Jika hanya untuk menyimpan sedikit data (beberapa variabel), maka mengunakan shared preferences seperti pada tahap investigasi mobile forensics yang melibatkan aplikasi pada sistem operasi Android Mobile. Shared Preferences adalah mekanisme untuk menyimpan pasangan key-value untuk tipe data primitif (integer, double, string,float, booelan dan string). Shared Preferences cocok untuk penggunaan data kecil seperti menyimpan setting aplikasi dan informasi mengenai user interface. Data dalam shared preferences disimpan dalam device android dalam bentuk XML. Shared preferences memiliki kondisi bilamana data cukup kompleks dan sering memerlukan pencarian (akses random) maka akan dibutuhkan database terkait, namun jika ukuran datanya besar dan tidak dibutuhkan sebuah pencarian spesifik maka dapat dialokasikan pada memori ekternal seperti MicroSD card untuk dapat dibaca komputer, atau memerlukan format yang yang sangat spesifik dalam penggunaannya.

\section{- Internal Storage}

Mobile Forensics Investigation dalam mengektraksi internal memori smartphone menggunakan Oxygen forensic dikarenakan tools Oxygen mengekstrak semua aplikasi didalam smartphone tak terkecuali WhatsApp yang dijadikan barang bukti penyadapan. Hal ini dapat terjadi diakibatkan smartphone android melakukan sinkronisasi account dengan phonebook. Proses sinkronisasi nantinya akan dikaitkan dengan aplikasi WhatsApp Web yang terdapat pada forensik browser pada komputer ber-platform windows

\section{- External Storage}

Pada proses investigasi pada ekternal memori dilakukan secara manual. Ekstraksi berbeda bila dibandingkan dengan mengekstraksi data pad smartphone. Proses ini dilakukan dengan membuat image dari digital evidence MicroSD card dengan menggunakan tools FTK Imager beserta proses analisisnya.

\section{- Network Capture (Simulasi Penyadapan Percakapan WhatsApp)}

Nmap bekerja pada ponsel root dan non root. Pada ponsel yang non root investigator dalam ekplorasinya akan terbatas pada fungsi yang dimungkinkan sebagai pengguna non-root (yaitu File System, Pemindaian SYN, dll.). Nmap ("Network Mapper") merupakan sebuah tools open source untuk eksplorasi berdasarkan paket data yang Nmap capturing. Nmap dirancang untuk memeriksa jaringan besar secara cepat, meskipun dapat pula bekerja terhadap host tunggal. Nmap menggunakan paket IP raw dalam cara yang canggih untuk menentukan host mana saja yang tersedia pada jaringan, layanan (nama aplikasi dan versi) apa yang diberikan, sistem operasi apa yang digunakan, apa jenis firewall/filter paket yang digunakan, dan sejumlah karakteristik lainnya. Meskipun Nmap umumnya digunakan untuk audit keamanan, namun banyak investigator forensik digital dalam mengawasi lalulintas data yang terdapat pada smartphone. Keseluruhan dari proses ekplorasi serta temuan dari investigasi mobile forensics terkait WhatsApp Messenger Smartphone Android dapat disajikan seperti Tabel 2 dan Tabel 3 :

Tabel 2. Android WhatsApp Forensics

\begin{tabular}{|c|c|c|c|c|}
\hline \multicolumn{4}{|c|}{ "Android" WhatsApp Application Data Storage Forensics } \\
\hline Shared Preference & Internal Storage & External Storage & Network Capture \\
\hline $\begin{array}{c}\text { File Type } \\
\text { stored }\end{array}$ & $\begin{array}{c}\text { Key-Value } \\
\text { XML format }\end{array}$ & $\begin{array}{c}\text { Dibutuhkan hak } \\
\text { akses } \\
\text { (Developer } \\
\text { mode/root) }\end{array}$ & Hak akses penuh & $\begin{array}{c}\text { ConGambarasi } \\
\text { data network } \\
\text { berbasis (capture } \\
\text { network accses) }\end{array}$ \\
\hline $\begin{array}{c}\text { Data } \\
\text { Type }\end{array}$ & $\begin{array}{c}\text { Integer, double, } \\
\text { string,float, booelan } \\
\text { dan string }\end{array}$ & $\begin{array}{c}\text { Ekstraksi data } \\
\text { (digital evidence) }\end{array}$ & $\begin{array}{c}\text { Ekstraksi data } \\
\text { (digital evidence) }\end{array}$ & hex values \\
\hline
\end{tabular}


Tabel 3. Android WhatsApp Forensics (Lanjutan)

\begin{tabular}{|c|c|c|c|c|}
\hline Location & $\begin{array}{c}\text { /data/data/co } \\
\text { m.android.phon } \\
\text { e/shared_prefs }\end{array}$ & $\begin{array}{c}\text { /data/data } \\
\text { subdirectory }\end{array}$ & $\begin{array}{c}\text { /mnt/sdcard or } \\
\text { emulated SD card } \\
\text { on/mnt/emmc }\end{array}$ & $\begin{array}{c}\text { log files } \\
\text { in/data/data/files }\end{array}$ \\
\hline $\begin{array}{c}\text { Level } \\
\text { Fovess }\end{array}$ & $\begin{array}{c}\text { Developer mode/ } \\
\text { root access }\end{array}$ & $\begin{array}{c}\text { Developer mode/ } \\
\text { root access }\end{array}$ & $\begin{array}{c}\text { Format FAT32 } \\
\text { (Recovery } \\
\text { Mode) }\end{array}$ & Network level \\
\hline $\begin{array}{c}\text { Forensic } \\
\text { Use }\end{array}$ & $\begin{array}{c}\text { Sumber data } \\
\text { forensik } \\
\text { (jika root access) }\end{array}$ & $\begin{array}{c}\text { Sumber data } \\
\text { forensik } \\
\text { (jika root access) }\end{array}$ & $\begin{array}{c}\text { Sumber data } \\
\text { forensik } \\
\text { (digital evidence) }\end{array}$ & $\begin{array}{c}\text { Sumber data } \\
\text { forensik } \\
\text { (log digital evidence) }\end{array}$ \\
\hline
\end{tabular}

Database SQLite dapat digunakan sebagai pendukung tindakan investigasi digital dalam kaitannya membantu penyidik untuk mengumpulkan artefak Whatsapp. Digital evidence dengan database WhatsApp memiliki data yang dapat diekplorasi sebagai barang bukti diantaranya ;

- File msgstore.db terletak di stuktur file android "/data/data/com. whatsapp" yang menyimpan pesan yang dikirim maupun diterima oleh pengguna aplikasi WhatsApp Smartphone.

- File wa.db terletak di lokasi yang sama "/data/data/com. whatsapp" dan menyimpan semua kontak WhatsApp.

\subsection{Windows (Computer Forensics)}

Windows Forensic Analysis berfokus pada investigasi forensik digital terhadap sistem operasi Microsoft Windows, dengan memahami konsep forensik dan artefak dari komponen inti platform windows beserta aplikasinya. Computer forensics akan membahas bagaimana memulihkan (Recovery), menganalisis (Analys), dan authentication data forensik pada sistem Windows, melacak aktivitas pengguna tertentu di aplikasi atau program file, dan mengidentifikasi temuan untuk digunakan dalam respon insiden digital forensik dalam hal ini kemampuan WhatsApp Web dalam membaca aplikasi sejenis pada smartphone dalam kaitannya litigasi tindak kejahatan cybercrime. Sama halnya tools akuisisi pada ekternal memori smartphone digunakan FTK Imager sebagai akuisisi data partisi beserta system windows yang nantinya akan dijadikan alat images barang bukti dalam kegiatan investigasi file dan folder pada hard disk local drive. FTK imager juga mempunyai peran penting dalam otoritas barang bukti digital, FTK mampu membuat file hash SHA1 atau MD5, mengekspor file dan folder dari images forensik ke disk partition, meninjau dan memulihkan file yang telah dihapus dari Recycle Bin (dengan syarat blok data mereka belum ditimpa), dan mount images forensik untuk melihat isinya di Windows Explorer.

\section{- Web Browser Forensics}

FoxAnalysis dan Chrome Analysis adalah perangkat lunak forensik untuk mengekstrak dan menganalisis riwayat internet dari browser web Chrome. Banyak jenis data dapat dianalisis termasuk kunjungan situs web, penelusuran, unduhan, file masuk tersimpan dan file dalam cache. Data yang diekstrak mencakup bookmark, cookies, download, login, situs yang paling banyak dikunjungi, sesi tersimpan dan kunjungan ke situs.

\section{- Restore Evidence dari SQLite Database}

Struktur database rekaman tentang pengguna WhatsApp disimpan di-disk partisi system windows. Investigator dapat megekplorasi file yang tersimpan hasil akses web browser baik yang terhapus atau sebagian dari struktur halaman SQLite. Recover data delete untuk mengakses bukti digital dari halaman yang dihapus, investigator forensik perlu menganalisa "Cell Pointer Array" yang merupakan jenis database yang menyimpan alamat setiap cell array. Analisis history browser atau forensik database SQLite hal ini dapat dibuktikan dengan mengekstrak bukti dari riwayat browser yang berisi informasi seperti ; download, password, web url, riwayat browser dan masih banyak lagi aktivitas penting lainnya. Tabel "url" adalah tabel yang paling relevan yang menyimpan informasi dari semua URL yang dikunjungi termasuk kontak server WhatsApp web.

\section{- Network Capture (Simulasi Penyadapan Percakapan WhatsApp)}

Wireshark Analys adalah tools yang ditujukan untuk melakukan analisa paket data jaringan. Wireshark melakukan monitoring paket secara real time selanjutnya Wireshark melakukan penangkapan data dan menampilkannya selengkap mungkin. Keseluruhan dari 
proses ekplorasi serta temuan dari investigasi web browser terkait WhatsApp web dapat disajikan seperti Tabel 4 :

Tabel 4. Windows WhatsApp Web Forensics

\begin{tabular}{|c|c|c|c|c|}
\hline \multicolumn{5}{|c|}{ "Windows" WhatsApp WebApplication Browser Forensics } \\
\hline & System Windows & $\begin{array}{l}\text { Web Browser } \\
\text { Forensics } \\
\text { (Mozilla) }\end{array}$ & $\begin{array}{l}\text { Web Browser } \\
\text { Forensics } \\
\text { (Chrome) }\end{array}$ & Network Capture \\
\hline$\left|\begin{array}{c}\text { File Type } \\
\text { stored }\end{array}\right|$ & $\begin{array}{l}\text { Databases } \\
\text { On System }\end{array}$ & $\begin{array}{c}\text { Cookies.sqlite } \\
\text { formhistory.sqlite } \\
\text { content-prefs.sqlite }\end{array}$ & $\begin{array}{c}\text { Cookies.sqlite } \\
\text { formhistory.sqlite } \\
\text { content-prefs.sqlite }\end{array}$ & $\begin{array}{c}\text { Paket data } \\
\text { captured network }\end{array}$ \\
\hline $\begin{array}{l}\text { Data } \\
\text { Type }\end{array}$ & $\begin{array}{l}\text { boolean, float, int, } \\
\text { long, strings }\end{array}$ & $\begin{array}{c}\text { Path of } \\
\text { database .sqlite }\end{array}$ & $\begin{array}{c}\text { Path of } \\
\text { database .sqlite }\end{array}$ & $\begin{array}{c}\text { Paket data } \\
\text { captured .pcap }\end{array}$ \\
\hline Location & 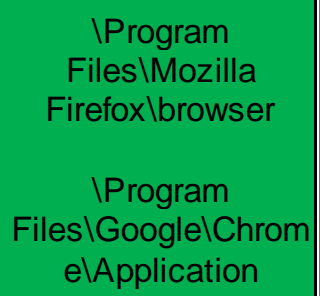 & $\begin{array}{l}\text { Users } \backslash \text { Administra } \\
\text { tor } \backslash \text { AppData } \backslash \text { Local } \\
\backslash \text { Mozilla\Firefox } \backslash \mathrm{Pr} \\
\text { ofiles }\end{array}$ & 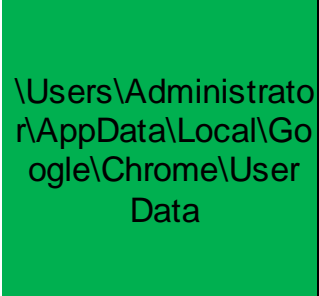 & $\begin{array}{c}\text { Log files } \\
\text { in/data/data/files }\end{array}$ \\
\hline $\begin{array}{l}\text { Access } \\
\text { Level }\end{array}$ & $\begin{array}{c}\text { Administrator } \\
\text { (image windows) }\end{array}$ & $\begin{array}{c}\text { Administrator } \\
\text { (image windows) }\end{array}$ & $\begin{array}{l}\text { Administrator } \\
\text { (image windows) }\end{array}$ & $\begin{array}{c}\text { Network } \\
\text { (level layer) }\end{array}$ \\
\hline $\begin{array}{c}\text { Forensic } \\
\text { Use }\end{array}$ & $\begin{array}{c}\text { Sumber } \\
\text { investigasi data } \\
\text { digital forensik }\end{array}$ & $\begin{array}{c}\text { Sumber } \\
\text { investigasi data } \\
\text { digital forensik }\end{array}$ & $\begin{array}{c}\text { Sumber } \\
\text { investigasi data } \\
\text { digital forensik }\end{array}$ & $\begin{array}{c}\text { Forensik data dari } \\
\text { hasil capture network } \\
\text { akses }\end{array}$ \\
\hline
\end{tabular}

Database SQLite dapat digunakan sebagai pendukung tindakan investigasi digital dalam kaitannya membantu penyidik untuk mengumpulkan artefak Whatsapp Web. Digital evidence dengan database WhatsApp Web memiliki data yang dapat diekplorasi sebagai barang bukti diantaranya ;

- Web Browser Forensics (Mozilla) IUsers|Administrator|AppDatalLocal|Mozilla|Firefox|Profiles

- Web Browser Forensics (Chrome) IUsers|Administrator|AppDatalLocallGooglelChromelUser Data

Berdasarkan data SQLite yang ditemukan di sub-directory diatas selanjutnya akan diektraksi database percakapan WhatsApp Web dengan metode tertentu (pengklasifikasian teks) sesuai dengan barang bukti WhasApp pada Smartphone.

\section{Kesimpulan}

WhatsApp telah menjadi aplikasi populer untuk jejaring sosial dimana orang dapat bertukar informasi pribadi beserta mobilitas yang mereka geluti. Penelitian ini telah menunjukkan bahwa seseorang dapat memperoleh akses lengkap ke semua informasi di WhatsApp baik itu WhatsApp Smartphone maupun WhatsApp Web. Sebagian besar aplikasi chat mengikuti pola sinkronisasi pesan, kontak dan data pengguna yang sama saat syinc dan memperbarui data percakapan secara berkala. Pendekatan yang diambil memberi garis besar umum untuk semua aplikasi serupa yang berjalan di perangkat ber-platform Android maupun Windows seperti Telegram dan sejenisnya. Penelitian ini dapat bermanfaat untuk Mobile Forensic Analysis dan Investigation pada smartphone Android dan aplikasi ganda berbasis web browser. Database $Q R$ 
Code membutuhkan autentikasi terhadap smartphone hanya sekali setiap saat login pertama kali sehingga dibutuhkan kewaspadaan penggunanya seperti penggunaan pattern lock pada smartphone dan login user password pada komputer penggunanya. Proses akuisisi langsung terhadap smartphone korban dan analisis web browser pada komputer. Diharapkan kedepan lebih banyak penelitian yang dapat dilakukan pada interpretasi data percakapan WhatsApp dalam bentuk jurnal atau naskah lain sebagai literatur selanjutnya.

\section{Referensi}

[1] Daniel Walnycky, Ibrahim Baggili, Andrew Marrington, Jason Moore, Frank Breitinger,(2015). Digital Investigation 14 (2015) S77eS84. DFRWS 2015 USA Network and device forensic analysis of Android social-messaging applications

[2] E.C., Turnbull, (2011). Digital Evidence on Mobile Devices, In E.Casey, Digital Evidence and Computer Crime (3rd Edition ed.), Academic Press, 2011.

[3] F.N. Dezfouli, A. Dehghantanha, B. Eterovic-Soric, K.-K.R. Choo, (2016). Investigating social networking applications on smartphones detecting Facebook, Twitter, Linkedln and Google+ artefacts on Android and iOS platforms, Aust. J. Forensic Sci. 46(4) (2016) 469488, http://dx.doi.org/10.1080/00450618.2015.1066854.

[4] Guntur Maulana Zamroni, Rusydi Umar, Imam Riadi. Analisis Forensik Aplikasi Instant $\begin{array}{lll}\text { Messaging } & \text { Berbasis } & \text { Android. } \\ \text { http://seminar.ilkom.unsri.ac.id/index.php/ars/article/view/808/741 }\end{array}$

[5] Hartanto, AAT. Panduan Aplikasi Smartphone, halaman 100. Gramedia Pustaka Utama, 2010. ISBN 100-6762-33-5

[6] Imam Riadi, Rusydi Umar and Arizona. (2016). Identification Of Digital Evidence On Android's Blackberry Messenger Using NIST Mobile Forensic Method. International Journal of Computer Science and Information Security (IJCSIS), Vol. 15, No. 5, May 2017

[7] M. Damshenas, A. Dehghantanha, R. Mahmoud,(2014). A survey on digital forensics trends, Int. J. Cyber Secur. Digit.Forensic. 3 (2014) 1-26.

[8] M. Taylor, G. Hughes, J. Haggerty, D. Gresty, P. Almond, (2012). Digital evidence from mobile telephone applications, Comput. Law Secur. Rev. 28 (2012) 335-339, http://dx.doi.org/10.1016/j.clsr.2012.03.006.

[9] Mubarak Al-Hadadi and Ali AIShidhani. (2013). Smartphone Forensics Analysis: A Case Study International Journal of Computer and Electrical Engineering, Vol. 5, No. 6, December 2013

[10] N Anwar, I. R. (2016). Forensic SIM Card Cloning Using Authentication. Int. J. of Electronics and Information Engineering Vol.4, No.2, PP.71-81, June 2016, 71-81.

[11] S. Mohtasebi, A. Dehghantanha, (2011). A mitigation approach to the privacy and malware threats of social network services, in : Digital Information Processing and Communications, Communications in Computer and Information Science, vol. 189, Springer, Berlin, Heidelberg, 2011, pp. 448-459, http://dx.doi.org/10.1007/978-3-642-22410-2_39.

[12] S. Mohtasebi, A. Dehghantanha, (2011). Defusing the hazards of social network services, Int. J. Digit. Inf. Wirel.Commun. 1 (2011) 504-516.

[13] S. Mohtasebi, A. Dehghantanha,(2013). Towards a unified forensic investigation framework of smartphones, Int. J. Comput. Theory Eng. 5 (2013) 351-355, http://dx.doi.org/10.7763/IJCTE.2013.V5.708.

[14] S. Mohtasebi, A. Dehghantanha, H.G. Broujerdi,(2012). Smartphone forensics: a case study with Nokia E5-00 mobilephone, Int. J. Digit. Inf. Wirel. Commun. 1 (2012) 651-655.

[15] Thakur, Neha S., Forensic Analysis of WhatsApp on Android Smartphones (2013). University of New Orleans Theses and Dissertations. Paper 1706.

[16] http://ensiklo.com/2015/01/bagaimana-cara-instalasi-whatsapp-untuk-desktop-pc-atau komputer/ (Senin 01 Juni 2017 12.23)

[17] https://www.statista.com/statistics/260819/number-of-monthly-active-whatsapp-users/ (Minggu, 18 Juni 2017 05.08) 